\title{
Strategies for Principal-Teacher Development: A South African Perspective
}

\author{
Vimbi P. Mahlangu \\ Department of Education Management and Policy studies, Faculty of Education, University of Pretoria, \\ South Africa, Corner Leyds and George Storrar Avenue, Groenkloof Campus Pretoria; 0002; \\ Email: vimbi.mahlangu@up.ac.za
}

\author{
Doi:10.5901/mjss.2014.v5n20p1378
}

\begin{abstract}
The aim of this article is to highlight the strategies used by school principals in facilitating their development and their teachers in primary schools in Limpopo and Mpumalanga Provinces of South Africa. The Department of Education in these provinces expects school principals and teachers to bring change in their school performances. The problem is that in these schools principals and teachers' professional developments is a challenge. Interviews were conducted with fifteen school principals who were purposively selected and their teachers completed a questionnaire. Professional development in the sampled schools was done in the form of workshops, individually guided staff development observation/assessment and training.
\end{abstract}

Keywords: teacher/educator, professional development, primary school, principal.

\section{Introduction}

The problem is that in Limpopo and Mpumalanga Provinces of South Africa principals and teachers' professional developments is a challenge. The question which this article seeks to understand is how are school principals and teachers developed? According to Clarke (2012), effective teams do not simply happen; they are developed by careful selection and good leadership. There are five types of teacher developments, namely: individually guided staff development; observation/assessment; involvement in a development/improvement process; training; and inquiry. In most cases teacher development is not properly done in schools (Sparks and Loucks-Horsley (1990). In this article the word teacher and educator will be used interchangeably. Teachers often enter the teaching profession with insufficient understanding of or experience with the diverse characteristics and needs of children in the geographic regions outside their university location (Hickey and Lanahan, 2012, p.171). Teachers cannot be trained once and for all. They need constant updating in new technology, pedagogic improvement and personal leadership development (Tomlinson, 1997, p.111). Professional development in this context refers to the principal when they update individual knowledge, skills, application of knew strategies and changes as well as improving their teachers' expertise. It is for individuals or groups with like needs identified by them or the school is career-orientated or personal and is longer term (Tomlinson, 1997, $\mathrm{p}$. 27).

In the past teacher preparation programs have historically focused on management skills (e.g., planning, strategic leadership, and financing; which are necessary but insufficient for meeting the adaptive challenges leaders of all kinds face in today's world. Instead, programs need a more holistic focus, one that also includes relational learning that is, a focus on building relationships), collaborative leadership, and reflective practice, and leaders must understand the nature of adult learning, the social-emotional dimension of leadership, adult development, and how to support these among adults in schools (Drago-Severson, Maslin-Ostrowski, \& Hoffman, 2012, p.48). Professional development in this context refers to the principal when they update individual knowledge, skills, application of knew strategies and changes as well as improving their teachers' expertise.

\section{Method}

Fifteen primary schools were used as research sites in the Limpopo and Mpumalanga Provinces. Qualitative approach was used in investigating the principal-teacher development strategies in primary schools. In qualitative approach the researcher relies on the views of participants; asks broad and general questions; collects data consisting largely of words or texts from participants; describes and analyses these words or themes and conducts the inquiry in a subjective, biased manner (Creswell, 2008, p.46). Desk top research, interviews using a tape-recorder and shadowing was done. Interviews were conducted with the principals of the fifteen schools and a questionnaire was completed by educators in the selected 
schools.

\section{The Role of the Principal}

School leaders remain of crucial importance for continued improvement of education. Within schools that are learning organisations evolve new types of relationship between students, teachers and leaders based around a reasonably common set of characteristics that include a trusting and collaborative climate, a shared and monitored mission, taking initiatives and risks, and on-going, relevant professional development (Mulford, 2003, p.2).

In understanding the principal teacher development strategies one need to ask "What is the leadership role of the principal?" In this article leadership is about providing direction, assuring alignment, building a commitment in educators and, facing adaptive challenges. Professional teaching is undermined by alternatives that avoid preparation for teachers because the defining features of a profession are that it is knowledge-based and client oriented. The knowledge professionals need in order to make sound decisions is transmitted through professional education and by initiation through supervised practice (Darling-Hammond, Wise, \& Klein, 1998, pp.16-17).

Principals are expected to be able to tolerate and cope with the inner conflict that arises between conflicting perceptions, needs, ideals, and duties of their schools. Each of us has our own unique set of skills, abilities and potential. Great leadership results are produced by maximizing our strengths. Overcoming competency gaps turbo-charges the use of these strengths (Hollweg, 2003, p.1-3). Principals can rely on applied transformational leadership in empowering teachers to fulfil their contractual obligations, meet the needs of the school, and go beyond the "call of duty" for the betterment of their schools (Santamaria \& Santamaria, 2012, p.3).

Principals are expected to inspire, motivate, and appeal to teachers through an array of skills and behaviours, which communicate their value to their schools. They serve as role models to others, modelling the characteristics, behaviours, and actions that they seek from all the members of the staff. The benefits of this leadership style are that the leaders improve the bottom line, which occurs as employees regularly surpass expectations; morale is increased through leaders' efforts to fully integrate followers into the core functions of the institution. Transformational leadership has a moral imperative wherein leaders aim to destroy old ways of life to make way for new ways of life, while articulating vision and values to keep empowered followers on a unified path (Santamaria \& Santamaria, 2012, p.3). These leaders redistribute power to their followers regardless of culture.

Principal- teacher development leadership needs to be purposive, inclusive, values driven; and to promote an active view of learning. For the leadership to be relevant it must be futures oriented and strategically driven. It must be developed through experiential and innovative methodologies. It needs to be served by a support and policy context that is coherent and implementation driven. Lastly, it should be supported by a National College that leads the discourse around leadership for learning (Crow, 2004, pp.289-299).

\section{Findings}

This part will be looking at the role of the principals in their own development; their role in the development of educators; and how do they help struggling educators? Each of the school's findings will be presented verbatim and separately.

\subsection{Which workshops, courses or programmes did you participate in while you are a principal?}

School LA: 'The leadership workshop. I usually enrol for leadership courses organised by the department of education apart from the ACE and the Honours Degree I had obtained. What I gained was how to manage and lead people. In University of Pretoria there was a module- "lead and manage people". How to lead people and how you manage people, when you do the wrong way that is when there will be problems. I learnt that when you lead people you do not leave them behind you lead with them you do not leave them at a distance'.

School LB: 'It is a continuation of my previous activities. I involve donors; we approached "Cash built "to help us. We approach the business people. The toilets are under renovation sponsored by a business firm in consultation with the department of education to ensure quality structure. On Friday there will be a handing over ceremony. The school is names after its former principal Mr X it is an old building with a lot of cracks that needs renovations. I am busy trying to get donors to help us develop the grounds for sports facilities to boost our Norms and Standards. We are also having a sewage problem and I have consulted the municipality of the issue'.

School LC: ' got permission to download this book from the internet. We have dropped from up to down so we must get back to the top. We have to learn to get back from the strategies recommend in this book. We should check the areas that we are lacking and try to improve on it. Like the use of technology we can check the internet to see how we can 
develop teachers in their weak areas. We sometimes employ people just to be in front of the children. There are some teachers that are appointed permanently, they may have weakness in teaching and this is where we come in to help them develop'.

School LD: 'After I attended the workshop on monitoring and assessing. This was for the department of education. We were taught to monitor the teachers and assessing them. I attended a workshop on SGB selection, after the workshop we called a parent meeting for induction, we told them about the election. We told them that the chair person they select must have love for the children in school, understand, and work together with educators. I also attended the HIVIAIDS training where we were taught not to discriminate learners with HIV because they are also people it is a disease like high blood pressure or cancer. We now have learner centred learning, learners must participate in class. The circuit manager is monitoring this'.

School LE: 'Policy assurance, IQMS, appraisal'.

School LF: 'Every second year we have...in Limpopo, all the school management teams get together - also the SAOU gives a workshop - it's a two day workshop...So the SMT members who are members of the SAOU get to go...All of them get together, yes... and it's usually a two-day workshop...we start after school on the first day and then the next day it's up to about four o'clock...And that deals with a variety of topics? Every...um...all the possible topics that a school's management needs...it's financial, um'...And do you find these workshops helpful? 'Very'...

School LG: 'Ja, there were a few...there is on a continuous basis...um...there are meetings and um... but it is not always focusing on equipping you for doing the job well. I must say that the SAOU (formerly an Afrikaans teachers association, lately an organisation with aims and functions more closely aligned with an educators' union) - they do create a lot...they do create opportunities, for example the annual symposium for principals in Port Elisabeth...um....where there's an...empowerment session...but from the Department of Education...um...very, very few. I did attend...there were some about finance management and um... but that was quite some time ago...many years ago.

School MA: 'Ja there a a number of them. Err the management workshop, governance workshop for school governing body and quality campaign management workshop introduced by the Mpumalanga Department of Education where they are encouraging us as leaders and also to involve the people in the teaching of learning of a learner and $i$ also attended err a music workshop while I was a principal. I also attended a school safety workshop for whereby they were work shopping us how we need to keep our school safe and how to involve err the people and I also attended the inclusive education workshop this is for the learners who are having barriers in learning'.

School MB: 'Quite a number of workshops. Courses that I think made an impact on me were courses on school leadership which I did through the University of South Africa. Workshop I attended in management leadership. Workshops on capacity building for SGBs, which I was at some stage delegated to run at the circuit. Those workshops assisted me to have clear capacity in terms of leadership of a school, and I was recommended to act as a circuit manager. I attended also the curriculum assessment policy workshop. I attended the strategic planning meeting for the circuit and the district. We are attending the SGB workshop tomorrow and Saturday'.

School MC: 'We I I I attended workshops, different workshops err for managers and leaders; and leaders, I also attended courses different programmes like err err school leadership management ja; management programmes which were arranged by the Department of Education'.

School MD: 'I think it's still the same because I attended workshops on subjects that I am teaching. I also attend safety workshops, SGB trainings. Strategic planning workshops. QLTC workshops; the curriculum workshops'.

School ME: 'Hmm the workshops I attended the management workshops, the curriculum workshops mostly also, the SGB Workshops, the school safety programmes, the school feeding programmes'.

School MF: 'While I was a principal? Uhm, there were plenty of them also that one has attended. I was trained as a trainer for, for, for SGB elections. I was one of the district trainees. I trained the whole circuit on that. Uhm, I am the Coordinator for Strategic Planning for the Circuit. And, then, uhm, I was trained on school management, a course by the department and leadership by the department. In-service training. In ACE I took Technology instead of school management which I will be completing in October with UKZN. And then I was also trained --there's a I successfully completed the trainer- of- the trainers Microsoft training. It's an initiative by Microsoft and Vodacom. I'm the only principal who completed that course. It's a computer course - trainer-of-the trainers. I'm actually supposed to be training educators on the utilization of ICT in teaching and learning'.

Interviewer: 'So, this was done here in Emalahleni?'

'It was done at Anglo-American Science and Technology Centre at Anglo mine. It's sort of like a teachers' centre'.

Interviewer: 'So, you've trained educators in the use of technology?'

'For teaching and learning. I've trained some [teachers] in the project but due to my responsibilities as a principal I could not go further. They actually wanted to take me out of the principalship and gave me an offer but I declined because I had to go train even outside the country. Then I told them that I love what l'm doing now and didn't want to leave my family and travel'.

School MG: 'Presently, there is a programme we are doing it with the University of the Free State. ACE in School Management and Leadership'.

Interviewer: 'How did you end up at UFS? Was it a district initiative?' 
'Ja, it is a district initiative. We started last year in September at White River and this year in Middelburg in January. The lecturers come to us from UFS'.

School MH: 'Mmm, it was induction by the Department of Education; the district. And then there was this support visit after induction. It was outreach. The induction lasted from 8 to 4 in one day. I also did my Honours through UP'.

\subsection{What is your role in the development of educators in your school?}

School LA: 'Usually, I use to say that it begins with me. I have to do the right thing, for example if I want them to come to school early, I must be in school early and if I want them to go to class I have to go to class. The way I do things should set example for the teachers. The way you walk and dress as a principal is important because the teachers will like to be like you. In controlling their work, we have SMTs and HODs. The HODs manage the curriculum, I check what the HODs are doing then I go to class to check if the learners work correlate with the HODs work'.

School LB: 'In terms of educator development we start from SMTs to educators, I delegated duties to staff members in written form. I develop policy even discipline matters including how to discipline learners. I capacitated my educators in not using corporal punishment. I explained to them the different levels of offences for example the learner failing to attend class that falls under level 1 and the kind of disciplinary measures that goes with it other than corporal punishment. You have to explain in a daily basis, I told them that they must display them in their classroom boards. The SACE code of conduct must be adhere to. How to communicate with the colleagues, learners and the parents. I told them about respect in communication. We have school development plan like IQMS'.

School LC: 'Initially, we did not have HODs. It was me and the staff. We did everything including appraisal. What we are doing now is that I do my own personal class visits I do not leave it to HODs only anymore because there was a time that I did it and I got complains from the parents asking me to move their children from one class to the next. When I asked why? They said that some teachers are not teaching while others are teaching. I spoke to the SMTs and the HOD and told them that you cannot be on page 17 and the teacher in your phase is on page 5 you are not on the same boat. That is when I started going to class. Unfortunately 0 can only do it for 2 weeks. The problem is that there are a lot of workshops during the beginning of the year, when February starts and it interferes with teaching and learning because you are away from the school. I am the IQMS cluster coordinator at schools. I must make sure that I start from home. I must sure that IQMS is implemented the was that it is supposed to -which is developmental. I tell them that it is not about $1 \%$ or $2 \%$ or $3 \%$ of money that is the focus at this school. The $1 \%$ is just an incentive to keep on working. The important thing is how I can get better, which areas are I lacking'.

School LD: 'To see to it that they are happy and supported. We sometimes call meetings with all educators and we look at the performance of the learners according to subject performance. Then we talk and all of them come up with intervention strategies. We check if they are improving the teachers also attend department workshop. We have funding, we have norms and standards for the workshop attendance but it is not sufficient like now it if February and the money is already finish. So maybe they will send more money for the workshops'.

School LE: 'We are only 3; we develop and help each other. When we have a problem we discuss and work it out together'.

School LF: 'Um...I am one of the people who...um...assist them in assessment, so I go to their classes and see how they handle a class situation, and I then give them support and we urge them on to do further training, especially those who only have one qualification. Then we have subject meetings and phase meetings - the subject meeting is for the specific subject that they teach and the phase meeting is for whether it is junior phase or intermediate phase and so on...

'And is there a developmental aspect to those meetings? Yes...yes...So that is something that is delegated from you to... The heads of departments...yes....and the subject heads'.

School LG: 'If I must...ja....in short I think, it is to create opportunities...um ...formal and informal...by saying that, if I talk about, more formal means making sure that they have got information regarding opportunities...um...where they can get better...um...qualifications...new course, new study opportunities...so to create opportunities, to provide them with information...to ensure that...um....well, I must make sure that I know them in the sense of their strong and their weak points...if I...I can't develop them and I can't be part of their development if I am not aware of areas in which they must be developed, so that for me is very important, and I am not doing that alone...the system of the school...the structure...the deputy principal, the heads of departments are all working together with that'.

Interviewer: You said informally, how would you describe that?

'That is on a daily basis...that is...um ...discussions taking place...it can be after the process of book control...um ...and getting the reports...going through the reports...asking the educator to come and see me, and in a very relaxed environment we will talk about certain things...even during break, even during school hours...ja'.

School MA: 'Err as a manager I have to see to it that my teachers are developed in so many areas like in teaching and learning number one and here err in this IQMS for educators they are also developing us and I try to develop them by inviting motivational speakers'.

School MB: 'I facilitate regarding issues that I detect to be a weaknesses. I facilitated Chapter 4 in the Employment 
Educators Act. For example the process of educators who want to retire and those that wants to resign, I felt it is important that teachers should have the knowledge of the process they should follow, so that they understand what is expected of them such that they do not flaw the process when they are about to retire. I have teachers who are about to retire; one is 51 years, the other is about 58, 59 years. That's what I normally do. I call a staff meeting in which we identify areas that need attention. I requested officials to come and conduct a workshop on leave matters in 2012'.

School MC: "I I help them using we have IQMS after discussing IQMS results with the PGPS then we set a program where we assist educators or where we develop them according to what we got in the IQMS. PGPS is progression growth program'.

School MD: 'I make sure they attend workshops and training all the time. And we hold staff meetings regularly. Although we have problems with holding phase meetings because we are only few. Those are called once per quarter. I always delegate them to do some of the office duties'.

School ME: 'My role is to ensure that my educators are developed, we have a programme here IQMS whereby the areas in which educators need development are developed; we visit them in their classes, and then we develop a plan to ensure that those areas that need attention are done'.

School MF: 'I think it's very key because I ... working with the SMT as the -- managing the curriculum, when we review the performance review, we identify the challenges that teachers have. Then we develop the School Improvement Plan. Which I must be central in the development of some of the teachers. I organise in-service training for them. I sometimes do the capacity building myself especially when it's about policies. Policy, I do it myself. From training them on the school and departmental policy, either curriculum or labour management-wise. I train them on teaching and learning ICT I deal with ICT. The recent project that the department has given to schools of 20 laptops, the Smart Labs I've already trained all my teachers how to use the Smart Labs. But the Department is still coming to train them -- but because I understood, I've already trained them; l've made it easier for all the teachers to be able to utilise in the classroom. Some schools are still sitting with these 20 laptops not knowing what to do. l've even arranged for additional connections. We do have the connection but it's limited. We bought extra dongles for the phases to be able to continue to teach. But we do have structured capacity building workshops within the school. I do it myself but sometimes, because they are used to me, I get someone from outside to train them. I know so many people to come and train them. Curriculum on teaching and learning in class; on subject specialisation what is their need. But I play a central role in seeing each and every teacher in the school is well-capacitated'.

School MG: 'We encourage them, Number 1, to register. Since l've arrived here, l've encouraged quite a number of them. How many? The other one is doing ECD. And then the other one is ... almost all the new ones, they've registered. I encourage them to register to improve their qualifications. And then, Number 2, also to develop them, we invite the outside motivators to come and motivate -- not only myself. Also the pastors from outside, they'll come and motivate. Sometimes we invite them for the learners but the very same teachers, they are also gaining. [inaudible] I'm also assisted -- external intervention. Also, we identify their problems from the IQMS and then from there, we sit down, I'll show you.... teacher development plan, we've done it where, for example, we have these new educators who come from the university. They don't know how to prepare a lesson plan. They don't know how to assess. They don't know about the curriculum per se. They don't know about the [inaudible]. Isn't it that the universities, they are too much abstract? But when here you have to come down to the level. So we sit down to develop them. So there is a programme that we've done'.

Interviewer: So, it's like an induction?

'Yes, induction programme, ja. I just want to show you... [show examples in files]. Here, all these educators, even myself when I have a challenge, I must indicate where my challenge is. Each and every one has a problem. Now, we pick a date; develop an activity plan to develop each other among ourselves. If I've got a challenge with assessment, not everyone has a challenge with assessment. The one who has experience, she'll capacitate us about assessment. This one has got the information about lesson planning and preparation and presentation. Also very good; inside and outside Even, I was marking the reports now. Her English is very good. Learners are getting 6, 7. So, on that capacity, we are sitting down to develop each other.

School MH: 'My role here is to mentor and to do coaching and motivation. I also do the delegation thing to develop them. I also invite the Cls to help the educators'.

\subsection{How do you help struggling teachers?}

School LA: 'It depends from which angle but in terms of the curriculum, for example I have a document that I have developed with the SMTs and I am taking it to the educators. The educators will read and agree, come with suggestions and input and we agree what to do but if the teacher is struggling as an individual, I will bring the teacher in my office and give him the policies. You see, at first you must provide the teacher with the tools to work with'.

School LB: 'I am concern with the late coming. I check the time book. When an educator is late I call her to my office and handle it well such that they tell me the challenge that they are having. I am always a good listener and I empathize with them. I have not seen a teacher who is aggressive. I have strict when it comes to curriculum coverage. We assist 
each other especially when it comes to challenges. I remind them of the policies and motivate them'.

School LC: 'They are the most difficult ones. The teachers who have diploma unfortunately, most of us think that we know it all. That is the biggest problem that we have in education, we do not need help and if we get help we ask why me? Why pick on me. I do it casually on occasion I ask them don't you have this page, I just want them to get use of me going to their class. I talk with the HOD and bring members of the SMTs when I do class visits. This is how we find the children. The marks tell me all'.

School LD: 'I once had an educator who had a problem in teaching mathematics. I asked an educator from another school to the teacher after teaching hours. That was the only one the other problems is lack of resources'.

School LE: 'Workload is too much. If one educator has to attend workshop it comes impossible to teach the learners'.

School LF: 'In the first place you must find out where the problems lies...is it a discipline problem ...is it a problem within the subject or is it a personal problem or extra-mural activity problem? Um...when that's sorted out, then there's certain people who can assist you in helping...if at this stage I experience it as a discipline problem, then I get involved myself and go to the class and discipline the children. When it's a problem with the subject, then I as the subject head to assist this specific teacher and also look at the subject meeting... help them with the subject meetings'.

School LG: 'Ja...um...I've already said that I...um....need to identify the areas in which they are struggling...I can't find ways of helping them if I am not aware of the fields in which they are struggling, so after identifying that, making use of our system, our structures at our school - there's heads of departments, there's subject heads...so very practically, if I do experience an educator struggling with the content of a specific subject, I will it to the subject head and ask the subject head to give guidance...so I am not trying to solve these problems on my own, I will only interfere or I will get involved if I have the time....and it was also going through my mind that if I think about helping educators who are struggling, I need to focus on the cause of the problem, and then manage that specific cause. It must also be said that of course there is also times when there's personal matters - problems at home...a crisis...um...a child that is ill or a husband that is in hospital, so in those areas

School MA: 'Ja we talk and try to assist them in their work. And however, if we cannot assist we involve the departmental officials. We are having Curriculum Implementers and then we involve them'.

School MB: 'I through the SMT determine where they need improvement. They agree to help the teachers in terms of the development plan. We draw a year plan but quarterly and identify teachers that need to be assisted. I assign HOD's to administer the progress, and the turnaround strategies'.

School MC: 'I have one on one session with them; I also advise them to to to go to other schools to get information if possible'.

School MD: 'I always encourage educators to work, to assist each other, to do peer teaching. If a teacher has a problem in a certain subject, the one who has the knowledge must assist'.

School ME: 'Through the class support visit'

School MF: 'Well, struggling educators; we start with them, acknowledging their challenges. Then we develop a turnaround strategy for them and then through the HoD's and the departmental officials, the Cl's, it's an academic programme, we engage all stakeholders for support and mentoring. If it's personal we engage one-on-one me and the educator. I always give advice; which route to follow, whether professionally or personally. That's how we deal with educators in the school. We actually have a policy on everything in the school which includes how we deal with supporting our colleagues in case of illnesses, bereavement, even things like weddings, parties, baby showers, visits, we do'.

School MG: 'Number 1; struggling educators; I call them to the office and from there we discuss as to where does the issue lie and then she will indicate and then from there l'll ask whether she has enough resources for that particular subject If she doesn't have enough resources like the textbooks or other or dictionaries, we'll go and buy. And also to give them the necessary support. Ja, the necessary support. It can be internal or external. They can be referred to a certain school to a certain teacher who is teaching that subject or to call the Curriculum Instructor (Cl) to come and assist. But firstly, I start internally'.

School MH: 'We actually do peer coaching and then I ask for assistance from the Cls'.

\section{Conclusion}

Principals develop themselves through workshops, donors' involvement; Internet; IQMS; teacher unions; universities (UNISA; UFS and University of Pretoria). They develop teachers by setting example, delegation, mentoring, coaching and motivation, SMTs and HODs involvement, through workshops, IQMS, and motivational speakers. Teacher development strategies used by some Mpumalanga and Limpopo schools are individually guided staff development, observation/assessment and training strategies in developing their teachers. The inquiry and teacher involvement in a development/improvement process is not used in both the provinces. 


\section{References}

Bradley, M.K., Kallick, B.O., \& Reagan, H.B. (1991). The Staff Development Manager: A Guide to Professional Growth. U.S.A: Allyn and Bacon.

Creswell, J.W. (2008). Educational Research: planning, conducting, and evaluating quantitative and qualitative research (3rd Edition). Pearson, Merrill Prentice Hall.

Crow, G.M. (2004). The National College for School Leadership: A North American Perspective on Opportunities and Challenges. Educational Management Administration \& Leadership 2004, 32, 289.

Drago-Severson, E., Maslin-Ostrowski, P., \& Hoffman, A.M. (2012). Resisting Fragmentation:Calling for a Holistic Approach to Professional Practice and Preparation for Educational Leaders. Journal of Research on Leadership Education 7(1), 44-77.

Dullah, J.J., Sharif, S., Nazarudin SMN \& Omar-Fauzee, S.M.S. (n.d.).

Headmaster's Transformational Leadership and Teacher's Organisational Commitment in Primary School. S. (Accessed on 3 June 2013).

Darling-Hammond, L., Wise, A.E., \& Klein, S.P. (1999). A License to Teach: Raising Standards for Teaching. San Francisco: JosseyBass Publishers.

Hickey, M.G., \& Lanahan, B.K. (2012). Even the Janitor is White: Educating for Cultural Diversity in Small Colleges and Universities. New York: Peter Lang.

Hollweg, L. (2003). Strength-focused Transformational Leadership. Insight Articles. Batrushollweg international. (http://www.southafrica.info/about/geography/limpopo).

Holly, M.L., \& Mcloughlin, C.S. (1989). Perspectives on teacher professional Development: Issues in Education and Training Series 11. London: The Falmer Press:

Mulford, B. (2003). School Leaders: Changing Roles and Impact on Teachers and School Effectiveness. A paper commissioned by the Education and Training Policy Division, OECD, for the Activity Attracting, Developing and Retaining Effective Teachers. April 2003.

Neumerski, C.M. (2012). Rethinking Instructional Leadership, a Review: What Do We Know About Principal, Teacher, and Coach Instructional Leadership, and Where Should We Go From Here? Educational Administration Quarterly 2013, 49, 310. Originally published online 27 August 2012.

Santamaria, L.J., \& Santamaria, A.P. (2012). Applied Critical Leadership in Education: Choosing Change. New York: Routledge.

Sparks, D., \& Loucks-Horsley, S. (1989). Five Models of Staff Development for Teachers. Journal of Staff Development 10, (4), 40-57.

Tomlinson, H. (1997). Managing Continuing Professional Development in Schools. London: Paul Chapman Publishing. 